\title{
Environmental Education
}

\section{Replacement of conventional plastic shampoo packaging for biodegradable ones - a survey}

\author{
Substituição de embalagens plásticas convencionais de xampus por \\ biodegradáveis - uma pesquisa
}

\author{
Laís da Costa Saboia 'ㄹ, Renata Nunes Oliveira ' \\ 'Federal Rural University of Rio de Janeiro, Seropédica, RJ, Brazil.
}

\begin{abstract}
Packaging is present in our daily lives, however, packaging for cosmetics is based on polymers from petroleum, which cause environmental impacts. A promising alternative would be the usage of biodegradable materials, such as biopolymers packaging. The present work proposed a survey to map public opinion about hygienic products change. 151 people from different segments of society answered the survey (questions related to environmental awareness, possible acceptability of changing traditional shampoos packaging for biodegradable ones). It was also observed the influence of the level of education on these choices. A large part of the participants was willing to accept products encased in biodegradable materials, but these group of people would have caution due to probable increase of price. In addition, there is a correlation between level of education and the attitude towards the environmental perspective, so those who studied more, tend to have more positive attitudes towards the environment.
\end{abstract}

Keywords: Biodegradable packaging; Environmental awareness; Cosmetic

\section{RESUMO}

Embalagens estão presentes no nosso dia a dia, porém, as embalagens para cosméticos são baseadas em polímeros de petróleo, que causam impactos ambientais. Uma alternativa promissora seria a utilização de materiais biodegradáveis, como embalagens de biopolímeros. O presente trabalho propôs uma pesquisa para mapear a opinião pública sobre a mudança de produtos de higiene. Responderam à pesquisa 151 pessoas de diferentes segmentos da sociedade (questões relacionadas à conscientização ambiental, possível 
aceitabilidade da troca de embalagens de xampus tradicionais por biodegradáveis). Também foi observada a influência do nível de escolaridade nessas escolhas. Grande parte dos participantes estava disposta a aceitar produtos envoltos em materiais biodegradáveis, mas esse grupo de pessoas teria cautela devido ao provável aumento de preço. Existe uma correlação entre o nível de escolaridade e a atitude perante a perspectiva ambiental, onde aqueles com maior escolaridade tendem a ter atitudes mais positivas em relação ao meio ambiente.

Palavras-chave: Embalagem biodegradável; Consciência ambiental; Cosmético

\section{INTRODUCTION}

Packaging has many functions, such as protection, promotion, delivery, and presentation of goods and it is also of importance in the conservation and safety of the product, maintaining its quality from manufacturing to consumption (IVANKOVIC et al., 2017). Mainly, the product needs to be protected from external environmental factors by means of barrier and mechanical properties, in order to preserve its characteristics without changing its quality (IVANKOVIC et al., 2017)(SONG et al., 2009)(PARKER, 2020)(DIAS; BASSO, 2017).

Traditionally, plastic has been the most used material on shampoo packaging and on many other products. Among other materials, hydrophobic polymers are widely used in packaging applications, leading to a large accumulation of residues, as these are nonbiodegradable and are also difficult to recycle or reuse (SONG et al., 2009).

However, the disposal of these packages causes high environmental impacts, which are increasingly alarming and need to be avoided. From 1950 to 2015, the world produced 8.3 billion tons of plastic - half of it was produced in the last 13 years - and less than $10 \%$ of the amount were recycled (PARKER, 2020).

Lately, relevant solutions in the packaging area are being used, in favor of sustainability and reduction of the environmental damage, such as the production of biodegradable packaging, using raw materials from renewable sources. Biodegradable 
polymers can degrade upon disposal by the action of living organisms. The interest in biodegradable polymers arises from their renewable source and end-of-life waste management by composting or anaerobic digestion to reduce the accumulation of waste (SONG et al., 2009).

The main disadvantages of conventional polymers are non-biodegradability, as they can take many years to be completely degraded, as well as they emit polluting gases into the atmosphere during their production (DIAS; BASSO, 2017). Hydrophobic polymers, are not biodegradable because of their long chains of molecules connected, sometimes crosslinked, so the microorganisms cannot break them down. Unlike the conventional ones, polymers made from natural plant materials or synthesized from renewable resources are easily microbiologically degradable, depending on the conditions they are exposed on their disposal (IVANKOVIC et al., 2017).

Bio-based polymers are mostly biodegradable by nature and produced from natural origins such as plants, animals, or microorganisms. Also, certain polyesters can be either synthesized from bio-derived monomers such as polylactic acid (PLA) (SONG et al., 2009). Their polymer chains can be broken through non-enzymatic processes, such as chemical hydrolysis. These are converted into $\mathrm{CO} 2, \mathrm{CH} 4$, water, biomass, and other small molecules (GROSS, 2002).

In this context, biodegradability means the possibility to hydrolysate at temperatures up to $50^{\circ} \mathrm{C}$, such as in composting, over a period of a couple months to one year. Polyester and copolyesters have been used widely during the past 20 years. Among these materials, polylactide (PLA) has proven to be the most attractive polymer of biodegradable polyesters. This highlight is due to several factors, such as easy obtainment through a biotechnological process - based on a lactobacillus strain - using cheap and abundant raw materials. PLA's degradation depends on time, temperature, low molecular weight impurities and catalyst concentration (GUPTA; KUMAR, 2007).

Among some advantages of PLA production, there are: the production consumes quantities of carbon dioxide; it promotes significant energy savings; it is recyclable and 
compostable; the physical and mechanical properties can be manipulated through the architecture of the polymer or formation of composites (AURAS; HARTE; SELKE, 2004).

PLA presents a medium water and oxygen permeability level comparable to polystyrene and its samples has controllable thermal and mechanical properties through composition. However, some features can make its use challenge, such as high density, high polarity, low heat resistance and brittleness (GUPTA; KUMAR, 2007)(AURAS; HARTE; SELKE, 2004)(TANG et al., 2012).

Composites are often the chosen alternative to improve properties of the isolated polymers, obtaining a more attractive material for a given application. Recently, nanocomposites have proven to be a promising option to improve barrier and mechanical properties. Nanocomposites based on montmorillonite (MMT) presented high mechanical and barrier properties while maintaining their biodegradability. The biopolymer-based nanocomposites with improved properties could potentially replace conventional packaging materials derived from non-renewable sources (TANG et al., 2012).

Avocado seed and avocado kernels, like other natural raw materials, can be incorporated into polymer matrices. They could form films with adequate mechanical properties; they have selective permeability to oxygen and carbon dioxide, due the presence of polysaccharides such as starch and cellulose derivatives an agro-industrial by-product, which generally has no other uses besides animal feed. Nonetheless, this seed has potential for application in biodegradable plastics/composites (FU; NETRAVALI, 2020)(DE ANDRADE, 2014)(BRITO, 2019).

Shampoos, conditioners, and other products are responsible for a high percentual of the cosmetics and personal care industry, which mostly uses/produces plastic bottles. Since these products are used by a large part of the population, the waste generated is quite expressive. In general, even though shampoo bottles are made of high-density polyethylene (HDPE), which is one of the most recyclable plastics, only $~ 12 \%$ of all shampoo bottles and other plastic containers are recycled each year in the United States. Biodegradable packaging can be an attractive alternative for reducing waste (BORUNDA, 2019)(LIFE, 2019). 
In this study, a survey was conducted to map the profile of people and their choices about conventional shampoo packaging and its environmental impact, in addition to checking the acceptability of a environment-friendly packaging.

\section{MATERIALS AND METHODS}

\subsection{Participants}

The survey was conducted online with 151 people through Google Forms, where people from different classes and levels of education could contribute, to map the behavior of consumers of various segments of society. Although the group of people of the present survey is small, at least a prediction was possible, based on the responses.

\subsection{Survey}

This survey had 12 questions (11 multiple choice and 1 open question). The questions were related to people's profile, choices, and preferences regarding the consumption of shampoos in non-biodegradable packaging, as well as the acceptability concerning a change of conventional packaging by biodegradable packaging. The survey questions were mainly multiple-choice ones, which could be answered by "Yes", "No" or "Maybe". The environmental awareness and acceptability of biodegradable packaging was examined by a series of questions inquiring about their satisfaction with conventional packaging and their environmental damage.

\subsection{Data analysis}

Plots were processed by the R Studio 4.0 .3 program. For statistical analysis, 4 ChiSquare tests were performed using Sigma Plot 14.5 to analyze if the answers to some questions are related to levels of education. All variables are categorical. The two variables were related in pairs, as:

1. Education level $x$ Satisfaction with their current shampoo packaging. 
2. Education level $\mathrm{x}$ Acceptability of exchanging conventional shampoo packaging for an environmentally friendly one.

3. Education level $x$ Concerns about the new shampoo packaging.

4. Education level $x$ Possible problems in this new packaging.

The Chi-Square test was used to test whether the variables in question are associated. The $p$-value was compared with the level of significance (alpha $=5 \%)$ - indicating a $5 \%$ risk of concluding that there is an association if there is not. If $p$-value $\leq$ alpha, it was concluded that variables had showed a statistically significant association, and the null hypothesis is rejected. If $p$-value > alfa, it is not possible to conclude that the variables are statistically associated, since there is not enough evidence, so the null hypothesis is not rejected.

\section{RESULTS AND DISCUSSIONS}

Regarding the inquiry about whether people care about the environment or not, all people responded positively, table 1 .

Table 1 - Answers to 3 questions of the survey

\begin{tabular}{lcc}
\hline \multirow{2}{*}{ Question } & \multicolumn{2}{c}{ Answer } \\
\cline { 2 - 3 } & “Yes" & "No" \\
\hline "Do you care about the environment?" & $100 \%$ & $0 \%$ \\
\hline "Are you satisfied with your current shampoo packaging?" & $20.53 \%$ & $79.47 \%$ \\
\hline "Would you accept changing your current shampoo packaging for an & $96.75 \%$ & - \\
environmentally friendly one?" & & \\
\hline
\end{tabular}

Source: Authors (2021)

Although $100 \%$ of the survey participants answered that they care about the environment, this response was somewhat controversial, according to the answers displayed in tables 1 and 2 (question: Are you satisfied with your current shampoo packaging?). It was not possible to infer that there is a correlation between education and satisfaction with the current packaging, mainly due to the large difference between the contingency of each group. However, there is a correlation through the chi square test. $20.53 \%$ of the participants 
were satisfied with conventional packaging, mostly composed of materials that pollute nature. At the same time, these participants claimed to be concerned about the environment, which may demonstrate that environmental awareness may be somewhat disconnected from environmental attitudes. The extent of environmental awareness is related to the nature of the damage and to the perception of real threats, that is, if people can see or feel a threateningsituation, the reaction and attitudes are likely to be more pronounced (KRAUSE, 1993). It might show that environmetal education is urgent for population. People's environmental knowledge is directly related to their environmental attitudes and behaviors. Those who have had a more detailed knowledge about environmental issues, demonstrated to make more conscious choices and to be active in face of environmental causes. This environmental knowledge refers to knowing the causes and consequences of environmental issues, as well as understanding the relation of responsibility between their attitudes and the environment (ZHENG, 2018).

Table 2. Answers of "Are you satisfied with your current shampoo packaging?" by level of education

\begin{tabular}{ccc}
\hline \multirow{2}{*}{ Level of education } & \multicolumn{2}{c}{ Answers } \\
\cline { 2 - 3 } & YES & NO \\
\hline Elementary School & $4.03 \%$ & $7.04 \%$ \\
\hline High School & $33.10 \%$ & $37.00 \%$ \\
\hline Higher Education & $37.10 \%$ & $25.90 \%$ \\
\hline Post-Graduate & $12.90 \%$ & $7.40 \%$ \\
\hline Masters & $5.60 \%$ & $7.40 \%$ \\
\hline Doctorate & $5.60 \%$ & $14.80 \%$ \\
\hline Post-doctorate & $1.60 \%$ & $0.00 \%$ \\
\hline
\end{tabular}

Source: Authors (2021)

The responses show a relevant openness and acceptance, since there was no negative response. This shows that even people who consider themselves satisfied with their current shampoo packaging, they would also choose to change it to a biodegradable one. Those who were more concerned about environmental problems, were more likely to agree to 
change the shampoo packaging into be biodegradable one, reaffirming that knowledge of environmental causes is closely related to choices and attitudes (BRITO, 2019). Only 3.25\% of the participants answered "Maybe", explaining that some people still do not feel completely comfortable with the use of this type of packaging. To better understand why these participants have doubts about the packaging, they were also asked about the problems that the new biodegradable packaging may cause, according to their perspectives.

A considerable portion (37.09\%), figure 1 and table 3, showed to be comfortable, without apprehension regarding the change of packaging. However, the most importants apprehensions would be: the increase in price $(56.29 \%)$, reduction in product quality and risks to the product, both (3.31\%). When changing the component materials of a packaging or the technology used for its manufacture, it is expected that the price of the product might change. The biodegradable product might a price similar to the conventioal product in order to encourage its usage. Consumers, in general, are willing to pay a little more for green and sustainable products - even if they don't fully understand these concepts. $3.42 \%$ of the participants demonstrated to be concerned with the quality of the product after the packaging change. Many people have shown very little knowledge of the terms "bioplastics", "biodegradable" and what they are composed of. Such a scenario can be quite favorable for there to be a suspicion about biodegradable materials, if there is an interaction with the product, bringing risks or decreasing its quality (BRITO, 2019).

(Continue...) 
Figure 1. Pie chart of the answers "What do you think that would be a problem with the new packaging?"

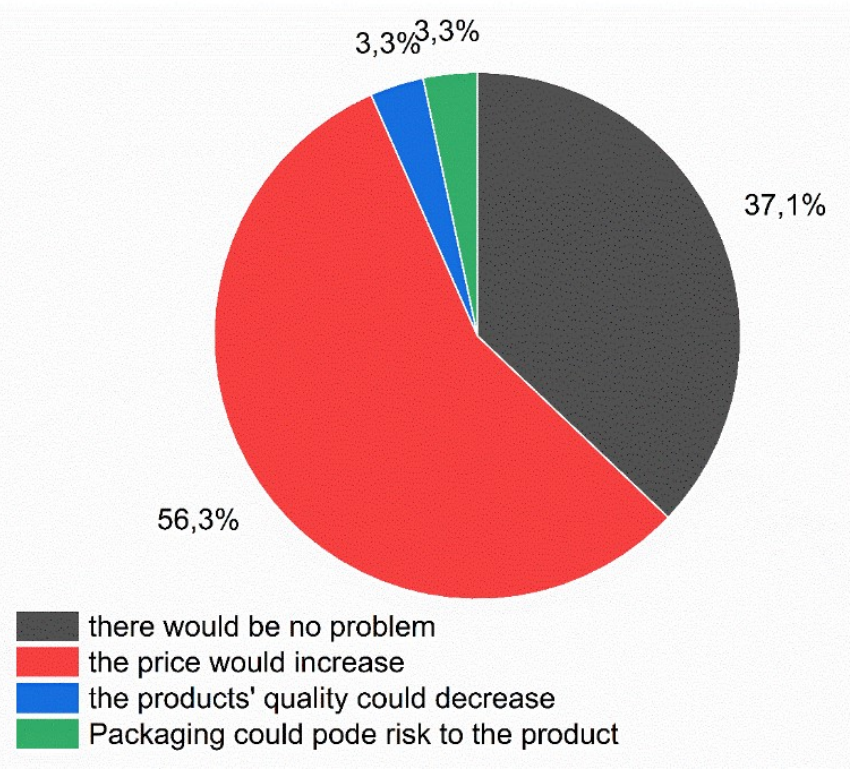

Source: Authors (2021)

Table 3. Answers to "What do you think that would be a problem with the new packaging?"

\begin{tabular}{ccccc}
\hline \multirow{2}{*}{$\begin{array}{c}\text { Level of } \\
\text { education }\end{array}$} & \begin{tabular}{c} 
Answers to the Question: What do you think that would be a problem with the \\
new packaging? \\
\cline { 2 - 5 }
\end{tabular} There would \\
be no problem & $\begin{array}{c}\text { The product's } \\
\text { price would be } \\
\text { higher }\end{array}$ & $\begin{array}{c}\text { The product's } \\
\text { quality could } \\
\text { decrease }\end{array}$ & $\begin{array}{c}\text { Packaging could pose } \\
\text { risks to the product }\end{array}$ \\
\hline $\begin{array}{c}\text { Elementary } \\
\text { School }\end{array}$ & $14.29 \%$ & $71.43 \%$ & $0.00 \%$ & $14.29 \%$ \\
\hline High School & $33.33 \%$ & $54.90 \%$ & $5.88 \%$ & $5.88 \%$ \\
\hline Higher Education & $39.62 \%$ & $58.49 \%$ & $0.00 \%$ & $0.00 \%$ \\
\hline Post-Graduate & $38.89 \%$ & $55.56 \%$ & $5.56 \%$ & $0.00 \%$ \\
\hline Masters & $33.33 \%$ & $55.56 \%$ & $11.11 \%$ & $0.00 \%$ \\
\hline Doctorate & $62.50 \%$ & $75.00 \%$ & $0.00 \%$ & $0.00 \%$ \\
\hline Post-doctorate & $100.00 \%$ & $0.00 \%$ & $0.00 \%$ & \\
\hline
\end{tabular}


Education can be a predicting factor of environmental knowledge and people's subsequent behavior. When analyzing the effect of education on environmental awareness, a significant relationship has been found between education and environmental attitudes. This implies that people with more years of formal education have a higher incidence of positive behavior towards the environment than those less educated (ARCURY, 1990). At the highest levels of education, table 4, most people have no apprehension about the new packaging. it was probably due to higher environmental knowledge, which brings them comfort with new sustainable technologies.

Table 4. Answers to "Do you have any concern about the new packaging?" according to the level of education

\begin{tabular}{ccc}
\hline \multirow{2}{*}{ Level of education } & \multicolumn{2}{c}{ Answer } \\
\cline { 2 - 3 } & “YES” & “NO” \\
\hline Elementary School & $28.57 \%$ & $71.4 \%$ \\
\hline High School & $7.8 \%$ & $92.2 \%$ \\
\hline Higher Education & $1.9 \%$ & $98.1 \%$ \\
\hline Post-Graduate & $0.0 \%$ & $100.0 \%$ \\
\hline Masters & $11.1 \%$ & $88.9 \%$ \\
\hline Doctorate & $9.1 \%$ & $90.9 \%$ \\
\hline Post-doctorate & $0.0 \%$ & $100.00 \%$
\end{tabular}

Source; Authors (2021)

\section{FINAL CONSIDERATIONS}

With the current concern of society in relation to the environment, the use of biodegradable packaging has proved to be a very attractive option to mitigate environmental damage. Thus, the replacement of conventional shampoo packaging is a step for this to occur. According to this research, it was possible to notice that there is considerable acceptability of this change, especially if the price of the product does not change, as well as the quality and safety of the product. In addition, there is a correlation 
between educational level and environmental attitudes, so those who studied more, tend to have more positive attitudes towards the environment. Environmental education seems to be key to change people's behavior, actions and choices regarding environmental causes.

\section{ACKNOWLEDGEMENTS}

The research was funded by FAPERJ (Research Support Foundation of the State of Rio de Janeiro), funding grant: E-26/200.647/2020. "This study was financed in part by the Coordenação de Aperfeiçoamento de Pessoal de Nível Superior - Brasil (CAPES) - Finance Code 001".

\section{REFERENCES}

ARCURY, THOMAS A. Environmental Attitude and Environmental Knowledge. Human Organization, [S. I.], v. 49, n. 4, p. 300-304, 1990.

AURAS, Rafael; HARTE, Bruce; SELKE, Susan. An Overview of Polylactides as Packaging Materials. Macromolecular Bioscience, [S. I.], v. 4, n. 9, p. 835-864, 2004. DOI: 10.1002/mabi.200400043. Disponível em: http://doi.wiley.com/10.1002/mabi.200400043.

BORUNDA, Alejandra. The beauty industry generates a lot of plastic waste. Can it change? 2019. Disponível em: https://www.nationalgeographic.com/environment/article/beauty-personal-careindustry-plastic.

BRITO, Jéssica Hoffmann. Produção e caracterização estrutural, morfológica e térmica de filmes biodegradáveis utilizando amido de caroço de abacate (Persea americana Mill) e bagaço de mandioca (Manihot esculenta Crantz). 2019. [S. I.], 2019.

DE ANDRADE, Roberta Melquiades Silva. Desenvolvimento e caracterização de filmes biodegradáveis à base de resíduos de frutas e hortaliças. 2014. [S. I.], 2014.

DIAS, Lucas Weber; BASSO, Nara Regina de Souza. Preparação de filmes poliméricos biodegradáveis para a aplicação em embalagens para cosméticos. 2017. [S. I.], 2017. Disponível em: http://tede2.pucrs.br/tede2/handle/tede/8178.

FU, Denghao; NETRAVALI, Anil N. Green composites based on avocado seed starch and nano- and micro-scale cellulose. Polymer Composites, [S. I.], v. 41, n. 11, p. 4631-4648, 2020. DOI: 10.1002/pc.25739. Disponível em: https://onlinelibrary.wiley.com/doi/10.1002/pc.25739. 
GROSS, R. A. Biodegradable Polymers for the Environment. Science, [S. I.], v. 297, n. 5582, p. 803807, 2002. DOI: 10.1126/science.297.5582.803. Disponível em:

https://www.sciencemag.org/lookup/doi/10.1126/science.297.5582.803.

GUPTA, A. P.; KUMAR, Vimal. New emerging trends in synthetic biodegradable polymers Polylactide: A critique. European Polymer Journal, [S. I.], v. 43, n. 10, p. 4053-4074, 2007. DOI: 10.1016/j.eurpolymj.2007.06.045. Disponível em:

https://linkinghub.elsevier.com/retrieve/pii/S0014305707003850.

IVANKOVIC, Anita; ZELJKO, Karlo; TALIC, Stanislava; BEVANDA, Anita Martinovic; LASIC, Marija. Biodegradable packaging in the food industry. Arch Lebensmittelhyg, [S. I.], v. 68, p. 26-38, 2017. DOI: $10.2376 / 0003-925 X-68-26$.

KRAUSE, Daniel. Environmental Consciousness. Environment and Behavior, [S. I.], v. 25, n. 1, p. 126142, 1993. DOI: 10.1177/0013916593251007. Disponível em:

http://journals.sagepub.com/doi/10.1177/0013916593251007.

LIFE, Unwrapped. THE CASE FOR PLASTIC-FREE SHAMPOO AND CONDITIONER. 2019. Disponível em: https://unwrappedlife.com/blogs/blog/the-case-for-plastic-free-shampoo-and-conditioner.

PARKER, LAURA. Em 2040, lixo plástico nos oceanos poderá ser o triplo do atual. national geographic, [S. I.], p. 1, 2020. Disponível em: https://www.nationalgeographicbrasil.com/meioambiente/2020/07/em-2040-lixo-plastico-nos-oceanos-podera-ser-o-triplo-do-atual.

SONG, J. H.; MURPHY, R. J.; NARAYAN, R.; DAVIES, G. B. H. Biodegradable and compostable alternatives to conventional plastics. Philosophical Transactions of the Royal Society B: Biological Sciences, [S. I.], v. 364, n. 1526, p. 2127-2139, 2009. DOI: 10.1098/rstb.2008.0289. Disponível em: https://royalsocietypublishing.org/doi/10.1098/rstb.2008.0289.

TANG, X. Z.; KUMAR, P.; ALAVI, S.; SANDEEP, K. P. Recent Advances in Biopolymers and BiopolymerBased Nanocomposites for Food Packaging Materials. Critical Reviews in Food Science and Nutrition, [S. I.], v. 52, n. 5, p. 426-442, 2012. DOI: 10.1080/10408398.2010.500508. Disponível em: http://www.tandfonline.com/doi/abs/10.1080/10408398.2010.500508.

ZHENG, Q. J. CORRELATION BETWEEN THE ENVIRONMENTAL KNOWLEDGE, ENVIRONMENTAL ATTITUDE, AND BEHAVIORAL INTENTION OF TOURISTS FOR ECOTOURISM IN CHINA. Applied Ecology and Environmental Research, [S. I.], v. 16, n. 1, p. 51-62, 2018. DOI:

10.15666/aeer/1601_051062. Disponível em: http://www.aloki.hu/pdf/1601_051062.pdf. 


\section{AUTHORSHIP CONTRIBUTIONS}

\section{1 - Laís da Costa Saboia}

Undergrad in Materials Engineering

https://orcid.org/0000-0003-3827-902X | laiscsaboia@hotmail.com

Contribuition: Conceptualization | Data curation | Investigation | Methodology | Writing original draft.

\section{2 -Renata Nunes Oliveira}

Professor of Materials Engineering at UFRRJ / Dr in Materials Engineering at UFRJ.

https://orcid.org/0000-0001-9782-269X | renatanunes.ufrrj@gmail.com

Contribuition: Conceptualization | Formal Analysis | Funding acquisition | Methodology |

Writing - review \& editing.

\section{HOW TO QUOTE THIS ARTICLE}

SABOIA,L.C; OLIVEIRA, R. N. Replacement of conventional plastic shampoo packaging for biodegradable ones - a survey. Revista de Gestão, Educação e Tecnologia Ambiental. Santa Maria, V. 25, e15, 2021. 21. Available from: https://doi.org/10.5902/2236117061358. Accessed: Month Abbreviated. Day, year. 